\title{
Behavior of Microorganisms from Wastewater Treatments in Extremely Low-Frequency Electric Field
}

\author{
Csaba Bartha ${ }^{1}$, Monica Jipa ${ }^{1}$, Alina-Ruxandra Caramitu ${ }^{2}$, Andreea Voina ${ }^{2, * \mathbb{D}}$, Attila Tókos ${ }^{1}$, Gabriela \\ Circiumaru $^{2 \mathbb{D}}$, Dan-Doru Micu ${ }^{3(\mathbb{D})}$, Iosif Lingvay ${ }^{1(\mathbb{D})}$
}

1 Research-Development Institute for Environmental Protection Technologies and Equipment S.C. ICPE Bistriţa S.A., Parcului Str., no. 7, RO-420035, Bistrita, Romania; csaba.bartha@icpebn.ro (C.B.); monica.jipa@icpebn.ro (M.J.); attila.tokos@icpebn.ro (A.T.); iosiflingvay@yahoo.com (I.L.);

2 National Institute for Research and Development in Electrical Engineering ICPE-CA Bucharest, 313 Splaiul Unirii, RO030138, Bucharest, Romania; alina.caramitu@icpe-ca.ro (A.-R.C.); andreea.voina@icpe-ca.ro (A.V.); gabriela.circiumaru@icpe-ca.ro (G.C.);

3 Techical University of Cluj Napoca - Faculty of Electrical Engineering, G. Bariţiu Str., no. 26-28, RO-400027, ClujNapoca, Romania; Dan.Micu@et.utcluj.ro (D.-D.M.);

* Correspondence: andreea.voina@icpe-ca.ro (A.V.);

Received: 30.07.2021; Revised: 8.09.2021; Accepted: 15.09.2021; Published: 17.10.2021

\begin{abstract}
The paper presents the research results regarding the metabolism of microorganisms from domestic wastewater treatment-activated sludge. The research approached this issue by dielectric spectroscopy measurements, chemical analyses, and specific microbiological techniques. In addition, the influence of extremely low-frequency (ELF) electric fields $(1 \div 500 \mathrm{~Hz})$ on microbial metabolism was studied. Four representative frequencies have been identified: 49.9, 99.9, 130.8, and $150.4 \mathrm{~Hz}$ using dielectric spectroscopy applied to the investigated samples. Also, dielectric loss and conductivity evolutions showed significant discontinuities, indicating oscillation/resonance phenomena in the investigated biomass, unlike the sterilized sludge samples (obtained either by boiling or electrically, applying a voltage that creates a $100 \mathrm{~V} / \mathrm{m}$ electric field strength on the sample), which did not show discontinuities; instead, the values of $\operatorname{tg} \delta$ and $\sigma$ were approx. 5-6 times larger. Chemical and microbiological tests have shown that the metabolism, growth, and multiplication of microorganisms in activated sludge are significantly increased after exposure to $4-6 \mathrm{~V} / \mathrm{m}$ electric field strength of $50 \mathrm{~Hz}$. The research may continue by developing equipment and a bioelectrotechnological process to significantly increase the efficiency of wastewater treatment plants.
\end{abstract}

Keywords: extremely low frequency (ELF); dielectric spectroscopy; microorganisms; active sludge; wastewater; water treatment.

(C) 2021 by the authors. This article is an open-access article distributed under the terms and conditions of the Creative Commons Attribution (CC BY) license (https://creativecommons.org/licenses/by/4.0/).

\section{Introduction}

In the perspective of sustainable development, water resources management is a priority issue with special social and economic implications. By their specificity, domestic and/or industrial wastewaters contain a wide spectrum of pollutants [1-5] which, after discharge into surface waters, determines their quality [6,9]. The use of wastewater - even treated - to irrigate plants leads to an increase in the heavy metal content of soil and groundwater [10]. Thus, wastewater treatment plants (WTP) are key infrastructure elements in water resources management. Under these conditions, the monitoring and efficiency of WTP operation are permanent concerns and are reported in many recent studies [11-15]. 
Most water purification plants (both waste and drinking water) present at least one biological treatment stage [4,14,16-20].

Biochemical processes are relatively slow and are the rate-limiting step in the water treatment processes. This explains the share of energy costs related to the water purification microbiological stages, usually over $60 \%$ of the total processing costs $[17,21]$.

On the other hand, as reported in [22-26], the biochemical processes and the living matter behavior are modified by electromagnetic fields (EMF) strength and frequency.

The research studies revealed that experimental conditions significantly influenced the results of the studies related to the influences of the EMF on living matter, especially by the frequency and strength of the applied EMF, dielectric properties of the analyzed samples, the geometry of experimental bioreactors, etc. [26].

Electromagnetic fields of anthropogenic origin can either positively influence both eukaryotic and prokaryotic organisms (growth stimulation [27,28] or negatively influence (growth inhibition) [27]. Microorganisms' growth stimulation can intensify the biotechnological processes in the electromagnetic field. For example, this technique can be applied to algae growing to obtain biofuels or biodegrade waste [27,28].

Recent studies made by dielectric spectroscopy showed that in the field of extremely low frequencies (ELF), microorganisms respond differently, depending on the applied ELF $[24,29,30]$, which is explained by dielectric relaxation in biological systems [31]. However, it has been experimentally found that the excessive increase of the applied electric field on the biomass leads to membrane permeabilization and, subsequently, to leakage of intracellular compounds [32].

Thus, in the present work, in order to develop a process that increases the energy efficiency of the water purification processes, we studied the effect of the ELF electric field on the microorganisms from the activated sludge sampled from the wastewater treatment plant.

\section{Materials and Methods}

The assessment of the ELF electric fields' effect on the microorganisms from the activated sludge in the domestic wastewater treatment plant of Romuli village (BN - RO county) was experimentally performed by dielectric spectroscopy technique and specific microbiological measurements.

The dielectric measurements of the activated sludge suspension were conducted using the STVP-200-XG thermostat system, equipped with a liquid sample holder, and by using the AMTEK - 1296 Dielectric interface (Solartron Analytical) specialized equipment. The measurements were performed at $12 \pm 0.5^{\circ} \mathrm{C}$ (average annual water temperature in the microbiological processing unit from the wastewater treatment plant). The recordings of dielectric loss tg $\delta$ were made in the range of $1 \div 500 \mathrm{~Hz}$ (for 1000 measuring points) at various voltages. Thus, the liquid sample holder with activated sludge samples was exposed to an electric field strength of $4,6,8$, and $100 \mathrm{~V} / \mathrm{m}$. Comparative dielectric measurements were performed both on activated sludge and on sterilized sludge which had been boiled for 10 minutes.

In the treatment process of domestic wastewater, to assess the activity of the microorganisms from the activated sludge, specific chemical and microbiological analysis were performed on biomass in experimental laboratory-scale reactors, with and without exposure to a $50 \mathrm{~Hz}$ electric field. Figure 1 illustrates the experimental setup. 


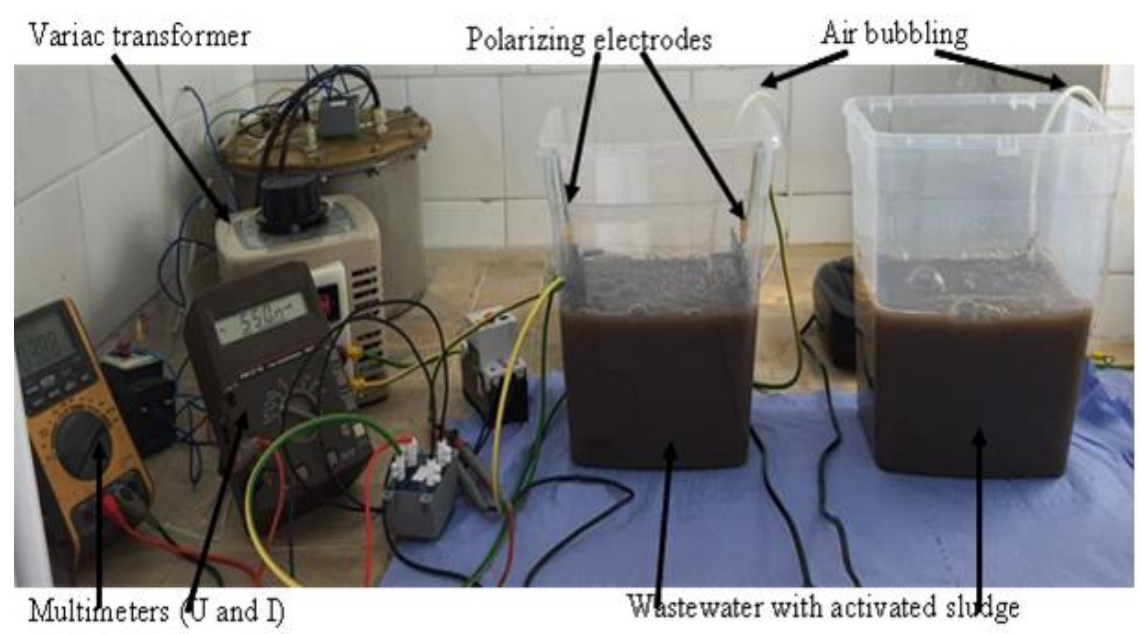

Figure 1. Experimental setup.

Comparative measurements were performed at $20 \pm 2^{\circ} \mathrm{C}$ (room temperature), by using synthetic wastewater with the following composition: $5 \mathrm{~g} / \mathrm{L}$ sugar, $0.401 \mathrm{~g} / \mathrm{L} \mathrm{NH}_{4} \mathrm{Cl}, 0.118 \mathrm{~g} / \mathrm{L}$ $\mathrm{K}_{2} \mathrm{HPO}_{4}, 0.032 \mathrm{~g} / \mathrm{L} \mathrm{MgSO} \cdot 7 \mathrm{H}_{2} \mathrm{O}$ and $0.03 \mathrm{~g} / \mathrm{L} \mathrm{FeSO} \cdot \cdot 7 \mathrm{H}_{2} \mathrm{O}$, all p.a. quality, MERCK, inoculated with $0.2 \mathrm{~L}$ of activated sludge suspension. Continuous aeration (bubbling $2 \mathrm{~L} / \mathrm{min}$ air) was applied to the bioreactor's synthetic wastewater (3L). Under these conditions, the evolution of the main water quality parameters was monitored using Photometric Cuvette Tests. Therefore, there have been measured:

- Dissolved oxygen - DO [mg/L], with a portable meter HQ40d, IntellicalTM LDO101 Probe (HACH-LANGHE);

- Chemical oxygen demand - COD [mg/L], according to ISO 6060-1989 (Dichromate method), using an LCK 114/Cuvette Test (HACH-LANGHE);

- Ammonium - [mg/L] - according to ISO 7150-1, DIN 38406 E5-1 and UNI 11669:2017 (Indophenol Blue method), using an LCK 303, 304/Cuvette Test (HACHLANGHE);

- Phosphate Ortho (total phosphor) - Pt [mg/L] - in accordance with ISO 6878-1-1986, DIN 38405 D11-4 (Phosphormolybdenum Blue method), using an LCK 348, 350/Cuvette Test (HACH-LANGHE).

To assess the growth of microbial culture in an environment with and without exposure to the electric field, the homogenized sludge samples were taken from the experimental bioreactors, then successively diluted until a $10^{-4}$ dilution, and subsequently spread on Luria Bertani (LB) agar plates. After 24 hours of incubation at $23 \pm 1^{\circ} \mathrm{C}$ and $95 \% \mathrm{RH}$, the samples were visually assessed/compared. The LB Agar plates were prepared by mixing $25 \mathrm{~g}$ dehydrated LB medium and $15 \mathrm{~g}$ bacteriological Agar in $1 \mathrm{~L}$ double distilled water. Then, the homogenized suspension was heated, sterilized, cooled at room temperature, poured into Petri dishes, and stored at $4{ }^{\circ} \mathrm{C}$ until used.

\section{Results and Discussion}

\subsection{Dielectric spectroscopy measurements.}

Figure 2 presents the results of dielectric spectroscopy recordings - the evolution of dielectric loss tg $\delta$ vs. frequency recorded on the activated sludge samples at $0.002,0.003$, and $0.004 \mathrm{~V}$ measuring voltages (corresponding to 4,6 , and $8 \mathrm{~V} / \mathrm{m}$ electric field strength in the liquid sample holder). 


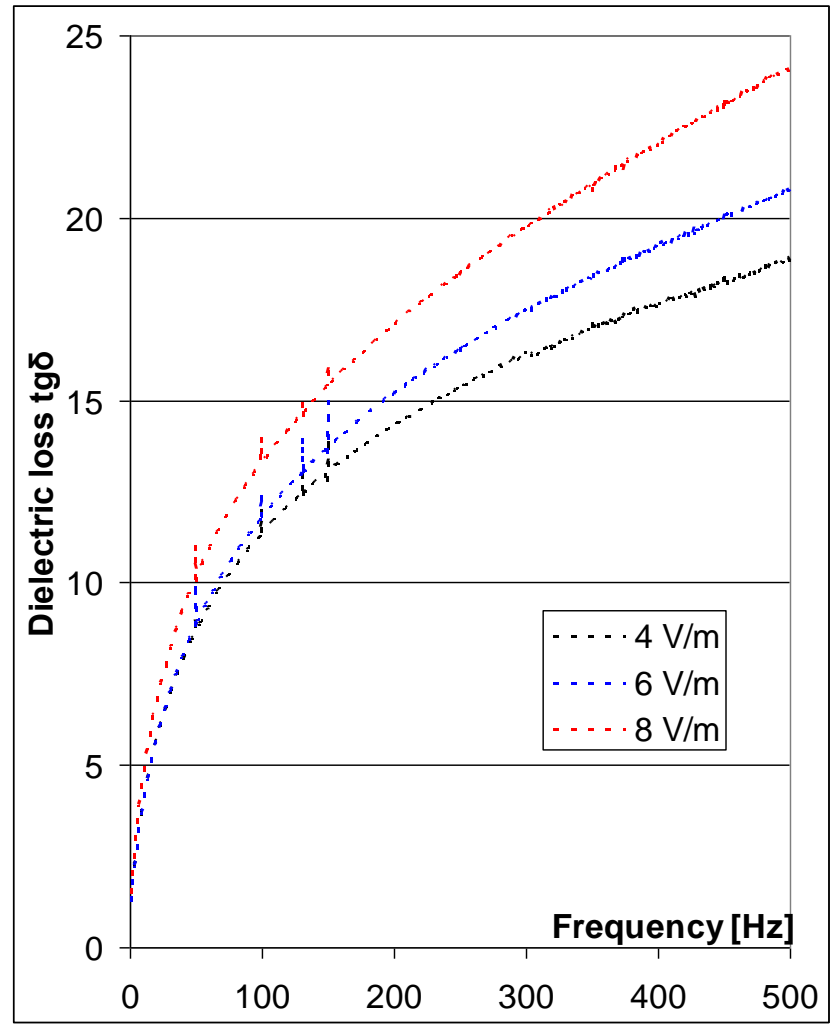

Figure 2. The evolution of $\operatorname{tg} \delta$ of activated sludge in the frequency range of $1-500 \mathrm{~Hz}$.

In Figure 2 can be noticed that at certain frequencies, the $\operatorname{tg} \delta$ vs. frequency curves show discontinuities, indicating that biochemical processes occur in the investigated environment; the number of charge carriers suddenly changes, which leads to corresponding changes in conductivity and thus in dielectric losses.

The variation of the dielectric loss $\Delta \operatorname{tg} \delta / \Delta \mathrm{f}$ is important in analyzing the effect of the ELF field on the investigated biomass. Therefore, in order to underline the frequencies to which the biomass metabolism is stimulated, these variations have been determined and are shown in Figure 3.

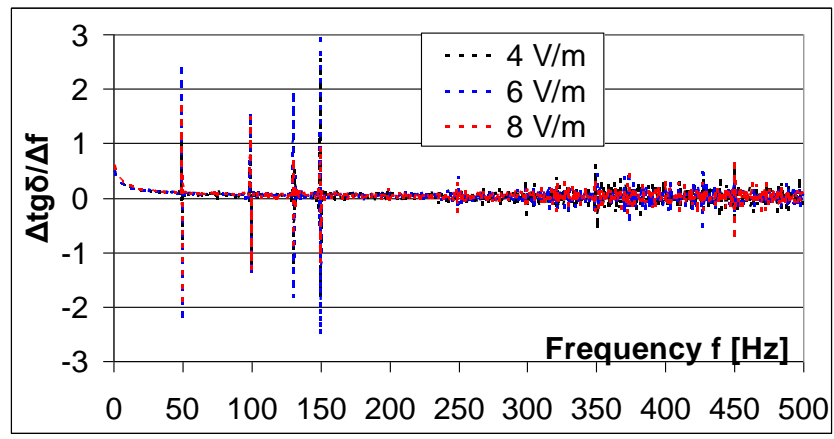

Figure 3. The evolution of $\Delta \operatorname{tg} \delta / \Delta \mathrm{ftg} \delta$ vs. frequency.

Figure 3 shows that at representative frequencies of 49.9, 99.9, 130.8, and $150.4 \mathrm{~Hz}$, significant kinetic changes occur in the metabolism of the microorganisms of the investigated biomass; thus, the biochemical processes from their cytoplasm are modified under the electric field action. The biomass behavior modifications indicate that dynamic processes take place. Thus, under the action of the ELF field, at these frequencies, the number of charge carriers in the investigated biomass is changed, suddenly changing probably due to the synchronisms in the ion-pumping steps in individual enzymes via a hold-and-release mechanism [33]. 
The results of the dielectric spectroscopy measurements performed on the activated sludge sample at $100 \mathrm{~V} / \mathrm{m}$ and on the sterilized sludge sample at $6 \mathrm{~V} / \mathrm{m}$ are summarized in Figures 4 and 5.

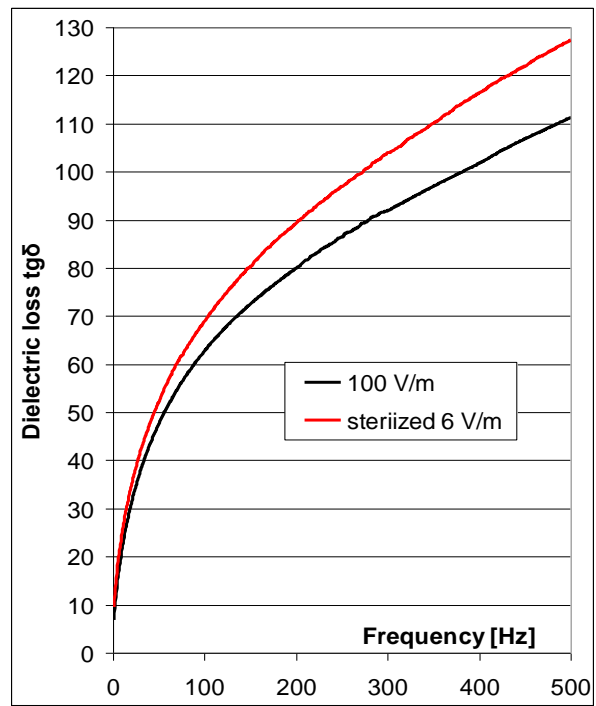

Figure 4. The evolution of $\operatorname{tg} \delta$ vs. frequency at $100 \mathrm{~V} / \mathrm{m}$ on activated sludge and at $6 \mathrm{~V} / \mathrm{m}$ on thermal sterilized sludge.

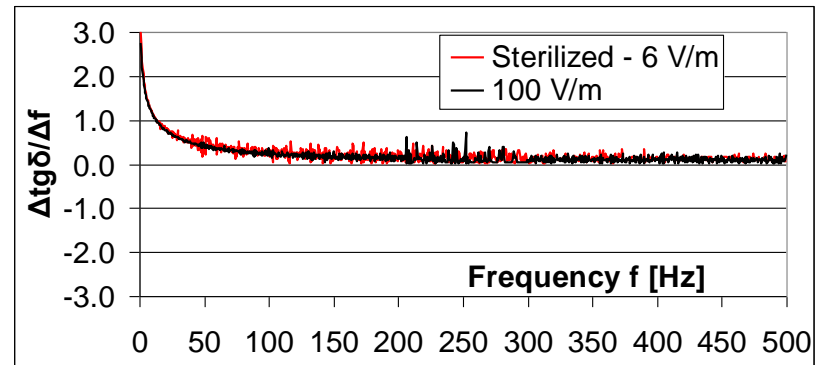

Figure 5. The evolution of $\Delta \operatorname{tg} \delta / \Delta \mathrm{ftg} \delta$ vs. frequency at $100 \mathrm{~V} / \mathrm{m}$ on activate sludge and at $6 \mathrm{~V} / \mathrm{m}$ on thermal sterilized sludge.

By analyzing Figure 4 results that in the case of the sterilized sample and activated sludge at $100 \mathrm{~V} / \mathrm{m}$, the evolution of tg $\delta$ vs. frequency are monotonously increasing continuous functions. This is confirmed (in the limit of experimental errors) by the $\Delta \operatorname{tg} \delta / \Delta \mathrm{f} v$ s. frequency evolution (Figure 5). It was also found that the recorded tg $\delta$ values (at the same frequencies) are systematically 6 times higher in the case of Figure 4 than in Figure 2.

These findings suggest that the biomass is practically sterilized by applying a larger measurement signal ( $100 \mathrm{~V} / \mathrm{m}$ compared to only $4 \div 8 \mathrm{~V} / \mathrm{m}$ as in Figure 2) (the electric discharge leads to membrane permeabilization, and consequently intracellular compounds leakage takes place). In the case of sterilized samples, the relatively high value of the dielectric loss is explained by the fact that after cell membrane destruction (through proteins thermal devolution or electric discharge), the operation of cellular ion pumps practically stops. The $\mathrm{Ca}^{2+}, \mathrm{Na}^{+}, \mathrm{K}^{+}$, $\mathrm{Mg}^{2+}$, etc. metal ions from cytoplasm become free (no longer concentrated in the cell membrane), freely diffusing into the extracellular fluid, significantly increasing the electrical conductivity $\sigma$ of the sterilized biomass. This finding is supported by the $\sigma$ values obtained by processing the data recorded through dielectric spectroscopy, as shown in Figure 6. 


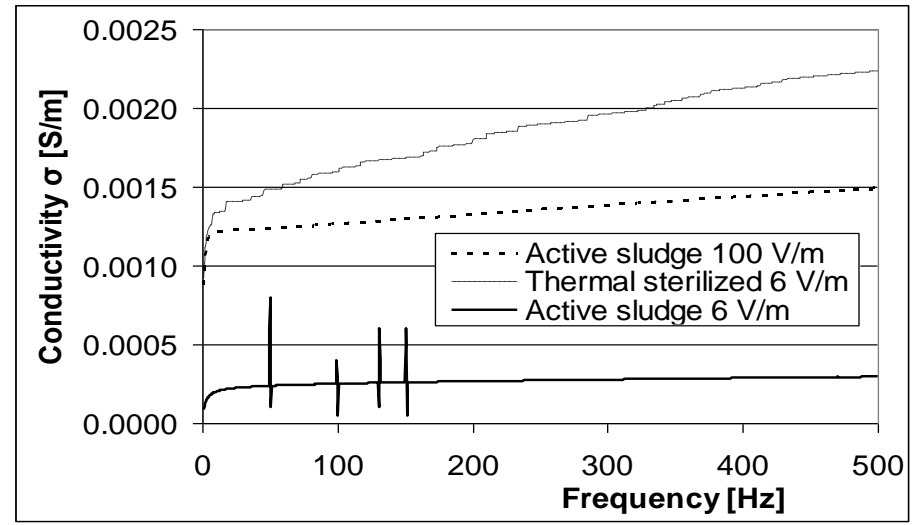

Figure 6. Conductivity vs. frequency for active sludge at $6 \mathrm{~V} / \mathrm{m}$ compared to electrical sterilized at $100 \mathrm{~V} / \mathrm{m}$ and thermal sterilized sludge.

By analyzing Figure 6, it is noted that the electrical conductivity of the sterilized samples (both by heating treatment and electrical by measurement at $100 \mathrm{~V} / \mathrm{m}$ ) is monotone continuously increasing function. It was also noted that the evolution of conductivity vs. frequency in the living matter sample (active sludge) has discontinuities (as expected) at 50, 100,130 , and $150 \mathrm{~Hz}$, and the sterilized samples $\sigma$ values are 5-6 times higher than those of the active sludge. This evolution of $\sigma$ (Figure 6) and tg $\delta$ (Figure 2) suggests that in activated sludge, oscillations disappear after the heating treatment at the respective frequencies. This behavior could be explained by the fact that in the living cells' cytoplasm, a series of dynamic processes occur like protein hydrolysis coupled with the condensation of the amino acid (processes governed/directed by the ion pumps inside the membrane), thus ensuring the synthesis of the enzyme necessary for cellular metabolism processes.

In the living matter, specific proteins are synthesized in different configurations by polycondensing of $\alpha$ amino acids (22 known proteins, 9 are essential [34] - which cannot be synthesized by eukaryotic cells). Amino acids are polar molecules with a positive charge concentrated near the $-\mathrm{NH}_{2}$ group and negative in the $-\mathrm{COOH}$ group. Depending on the dipole moment, the size of the aliphatic side chain, and the environment viscosity, each $\alpha$ amino acid has a relaxation time and, consequently, a specific resonance frequency. Following the ELF field application, depending on the applied frequency, certain $\alpha$ amino acids resonate, and thus their activation energy is reduced. As a result, the reactivity in biochemical processes is increased, leading to a given protein (enzyme) formation. Therefore, both the oscillations (the discontinuities at frequencies given in Figure 2, Figure 3, and Figure 6) and the experimental results reported in $[24,35]$ can be explained.

\subsection{Microbiological activity experimental results.}

The comparative experimental results related to the microbiological activity in the domestic wastewater treatment process of the activated sludge microorganisms, with and without exposure to $50 \mathrm{~Hz}$ electric field strength $\mathrm{E}$, are summarized in Table 1.

Table 1. Effects of $50 \mathrm{~Hz}$ electric field on microorganisms activity from the wastewater treatment plant activated sludge - water quality parameters evolution over time.

\begin{tabular}{c|c|c|c|c|c}
\multirow{2}{*}{$\begin{array}{c}\mathbf{E} \\
{[\mathbf{V} / \mathbf{m}]}\end{array}$} & \multirow{2}{*}{$\begin{array}{c}\text { Time } \\
{[\text { hours }]}\end{array}$} & $\begin{array}{c}\text { DO } \\
{[\mathbf{m g} / \mathbf{L}]}\end{array}$ & $\begin{array}{c}\text { COD } \\
{[\mathbf{m g} / \mathbf{L}]}\end{array}$ & $\begin{array}{c}\mathrm{N}-\mathrm{NH}_{4}^{+} \\
{[\mathbf{m g} / \mathbf{L}]}\end{array}$ & $\begin{array}{c}\mathbf{P}_{\mathbf{t}} \\
{[\mathbf{m g} / \mathbf{L}]}\end{array}$ \\
\hline \multicolumn{2}{c|}{ Initial } & 0 & 3210 & 59.4 & 10.1 \\
\hline 0 (reference) & 6 & $1.19 \& 22.1^{\circ} \mathrm{C}$ & 2940 & 37.20 & 6.45
\end{tabular}




\begin{tabular}{|c|c|c|c|c|c|}
\hline \multirow{5}{*}{$\begin{array}{c}\mathbf{E} \\
{[\mathbf{V} / \mathbf{m}]}\end{array}$} & \multirow[b]{2}{*}{$\begin{array}{c}\text { Time } \\
\text { [hours] }\end{array}$} & \multicolumn{4}{|c|}{ Parameter } \\
\hline & & $\begin{array}{c}\text { DO } \\
{[\mathrm{mg} / \mathrm{L}]}\end{array}$ & $\begin{array}{c}\text { COD } \\
{[\mathrm{mg} / \mathrm{L}]}\end{array}$ & $\begin{array}{r}\mathrm{N}-\mathrm{NH}_{4}^{+} \\
{[\mathrm{mg} / \mathrm{L}]}\end{array}$ & $\begin{array}{c}\mathbf{P}_{\mathbf{t}} \\
{[\mathrm{mg} / \mathrm{L}]}\end{array}$ \\
\hline & 12 & $1.96 \& 22.4^{\circ} \mathrm{C}$ & 2844 & 19.65 & 4.50 \\
\hline & 24 & $2.67 \& 22.3^{\circ} \mathrm{C}$ & 2643 & 1.23 & 3.69 \\
\hline & 48 & $3.32 \& 22.6^{\circ} \mathrm{C}$ & 1790 & 0 & 1.18 \\
\hline \multirow{4}{*}{1.5} & 6 & $1.25 \& 22.1^{\circ} \mathrm{C}$ & 2932 & 37.55 & 5.95 \\
\hline & 12 & $2.05 \& 22.4^{\circ} \mathrm{C}$ & 2795 & 17.55 & 4.12 \\
\hline & 24 & $2.92 \& 22.3^{\circ} \mathrm{C}$ & 2505 & 0.83 & 3.34 \\
\hline & 48 & $3.65 \& 22.6^{\circ} \mathrm{C}$ & 1357 & 0 & 1.05 \\
\hline \multirow{4}{*}{4} & 6 & $1.37 \& 22.1^{\circ} \mathrm{C}$ & 2397 & 20.15 & 5.55 \\
\hline & 12 & $2.93 \& 22.4^{\circ} \mathrm{C}$ & 2005 & 1.92 & 2.13 \\
\hline & 24 & $3.95 \& 22.3^{\circ} \mathrm{C}$ & 1180 & 0 & 1.22 \\
\hline & 48 & $4.10 \& 22.6^{\circ} \mathrm{C}$ & 1015 & 0 & 0.55 \\
\hline \multirow{4}{*}{6} & 6 & $1.45 \& 22.1^{\circ} \mathrm{C}$ & 2330 & 19.29 & 5.4 \\
\hline & 12 & $3.21 \& 22.4^{\circ} \mathrm{C}$ & 1775 & 1.68 & 2.01 \\
\hline & 24 & $4.12 \& 22.3^{\circ} \mathrm{C}$ & 1247 & 0 & 1.10 \\
\hline & 48 & $4.21 \& 22.6^{\circ} \mathrm{C}$ & 974 & 0 & 0.49 \\
\hline
\end{tabular}

Data presented in Table 1 show that, by exposing the sludge suspension to a $50 \mathrm{~Hz}$ electric field of $1.5 \mathrm{~V} / \mathrm{m}$, the metabolism of the microorganisms relatively insignificantly accelerates (compared to the control sample without electric field exposure), the pollutant content decreases, COD from $1790 \mathrm{mg} / \mathrm{L}$ to $1357 \mathrm{mg} / \mathrm{L}$ (approx. $24 \%$ at 48 hours), $\mathrm{N}-\mathrm{NH}_{4}^{+}$ from $1.23 \mathrm{mg} / \mathrm{L}$ to $0.83 \mathrm{mg} / \mathrm{L}$ (approx. $32 \%$ at 24 hours), Pt from $1.18 \mathrm{mg} / \mathrm{L}$ to $1.05 \mathrm{mg} / 1$ (approx. $11 \%$ at 48 hours). Accordingly, water dissolved oxygen level increases from 3.32 $\mathrm{mg} / \mathrm{L}$ to $3.65 \mathrm{mg} / \mathrm{L}$ (approx. 10\%). The metabolism of microorganisms is significantly accelerated by applying a 4 and $6 \mathrm{~V} / \mathrm{m}$ electric field strength. At $6 \mathrm{~V} / \mathrm{m}$, the COD decreases by approx. $45 \%$ (in 48 hours), $\mathrm{N}-\mathrm{NH}_{4}^{+}$decreases with over $90 \%$ in only 12 hours and $\mathrm{Pt}$ with approx. 58\% (in 48 hours). This significant decrease in pollutants content leads to an increase in the oxygenation level. DO increases by approx. $27 \%$ in 48 hours. There are no significant differences between the parameters recorded at $4 \mathrm{~V} / \mathrm{m}$ and $6 \mathrm{~V} / \mathrm{m}$.

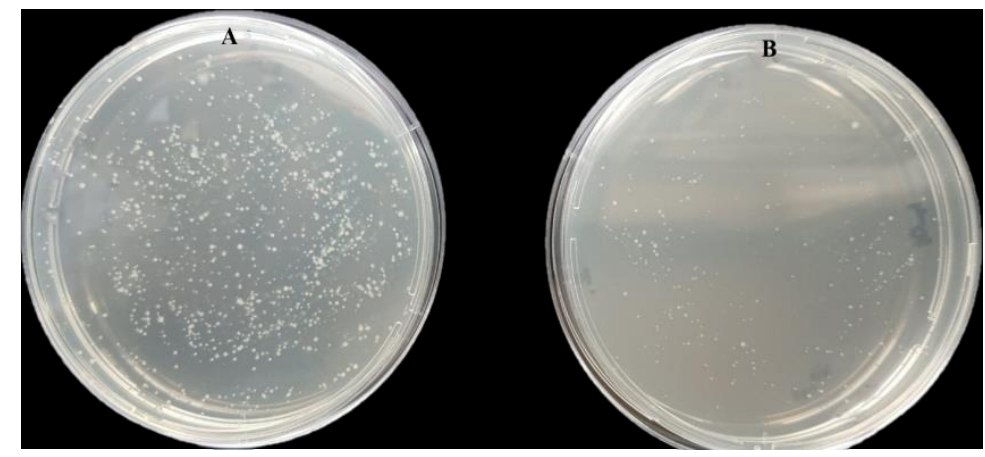

Figure 7. Bacterial colonies formed on LB agar medium, inoculated with $10^{-4}$ dilution samples of activated sludge after 24 hours; A - sample exposed to $6 \mathrm{~V} / \mathrm{m}(50 \mathrm{~Hz})$, B - sample not exposed to the electric field.

Table 1 shows that after exposure to $4 \mathrm{~V} / \mathrm{m}$ and $6 \mathrm{~V} / \mathrm{m}$, the decrease in pollutant content is significant after the first 6 hours of exposure. This suggests that the LAG phase period significantly decreases by applying a $50 \mathrm{~Hz}$ field (the microorganisms adaptation to environment and food source conditions stage [36]). These findings are also underlined by Figure 7 that shows the effect of the electric field on the bacteria multiplication rate from the activated sludge - comparison between the control sample (B), without exposure to the electric field and the sample (A) after 6 hours exposure to a $6 \mathrm{~V} / \mathrm{m}$ electric field strength, at $50 \mathrm{~Hz}$. 
Figure 7 shows that after 6 hours of treatment, under the same temperature and aeration conditions, in the sample exposed to $50 \mathrm{~Hz}, 6 \mathrm{~V} / \mathrm{m}$ electric field strength, the bacterial colonies formed are significantly higher than the control sample. This indicates - in good correlation with those reported in [37] - that the $50 \mathrm{~Hz}$ electric field accelerates the activated sludge microorganisms' metabolism and stimulates their growth and multiplication rate, respectively.

Based on these experimental results, the efficiency of domestic wastewater treatment plants can be substantially increased (by reducing the aeration stage and the microbiological treatment time and, therefore, the specific energy consumption). The results may continue by implementing bioreactors with electric field stimulation in a wastewater treatment plant [38] and developing a prototype bioreactor, and performing tests to evaluate its operation efficiency.

\section{Conclusions}

The influence of ELF electric fields on the activated sludge microbial metabolism was studied by dielectric spectroscopy technique and specific chemical and microbiological measurements. The activated sludge resulted from the domestic wastewater microbiological treatment stage. Following the experimental data processing and analysis, it was found that: in the investigated frequency range $1 \div 500 \mathrm{~Hz}$, the samples exhibit typical frequencies at 49.9, $99.9,130.8$, and respectively $150.4 \mathrm{~Hz}$; the evolution of dielectric loss and conductivity shows significant discontinuities indicating oscillation (resonance) phenomena in the investigated biomass; the dielectric loss and conductivity evolution recorded on sterilized biomass (by boiling or by applying a voltage that creates a $100 \mathrm{~V} / \mathrm{m}$ electric field strength on the sample) does not present discontinuities. However, the values of $\operatorname{tg} \delta$ and $\sigma$ are of approx. 5-6 times higher than those obtained on activated sludge; this indicates that cell membranes are destroyed by sterilization and do not ensure the ion pumps function; the metabolism, growth, and multiplication rate of microorganisms in activated sludge are significantly increased after biomass exposure to a 4-6 V/m electric field strength of $50 \mathrm{~Hz}$.

These results prove that the efficiency of the domestic wastewater treatment plants can be considerably increased by decreasing the aeration and microbiological treatment stages time and, consequently, the specific energy consumption.

\section{Funding}

This research was funded by a grant from the Romanian Ministry of Education and Research, CCCDI- UEFISCDI, project number PN-III-P2-2.1-PTE-2019-0139, within PNCDI III.

\section{Acknowledgments}

\section{Conflicts of Interest}

The authors declare no conflict of interest.

\section{References}

1. Yoswaty, D.; Effendi, I.; Mardalisa, M.; Efriyeldi, E.; Maulid Makwa, A. M.; Dzikri, M. F. The Threat of Microplastic Waste in Dumai Waters, Province of Riau, Indonesia. Carpathian Journal of Earth and Environmental Sciences 2021, 16, 383-390, https://doi.org/10.26471/cjees/2021/016/183. 
2. Banciu, A. R.; Ionescu, L.; Ionica, D. L.; Vaideanu, M. A.; Calinescu, S. M.; Nita-Lazar, M.; Marutescu, L.; Popa, M.; Chifiriuc, M. C. The evolution of the bacterial community between hospitals, wastewater treatment plants and the aquatic environment. Rev. Chim. 2020, 71, 313-316, https://doi.org/10.37358/RC.20.4.8070.

3. Cirtina, D.; Mihut, M. N. Study on the Assessment of the Oxygen Regime and the Nutrients Content of Some Water Streams in Gorj County. Rev. Chim. 2020, 71, 315-323, https://doi.org/10.37358/RC.20.2.7931.

4. Muntenita, C.; Dragomir Balanica, C.M.; Simionescu, A. G.; Stanciu, S.; Popa, C. L. The Efficiency of Biological Total Phosphorus Removal Process. Rev. Chim. 2019, 7, 1920-1923, https://doi.org/10.37358/RC.19.6.7247.

5. Dragomir Balanica, C. M.; Simionescu, A. G.; Popa, C. L.; Bichescu, C-I.; Muntenita, C. A Medium-term Analysis of Wastewater from an Agricultural Area. Rev. Chim. 2019, 70, 1664-1666, https://doi.org/10.37358/RC.19.5.7188.

6. Frîncu, R-M.; Iulian, O. Impact of Bucharest Wastewater on Dambovita River Water Quality (2010-2015). Carpathian Journal of Earth and Environmental Sciences 2021, 16, 47-58, http://dx.doi.org/10.26471/cjees/2021/016/154.

7. Moroșan, I-C.; Lobiuc, A.; Ivănescu, L. C.; Olaru, Ş. M.; Costică, N.; Zamfirache, M. M. Ludwigia Glandulosa (Walter, 1788) as a Potential Bio Indicator of Water Quality. Carpathian Journal of Earth and Environmental Sciences 2020, 15, 369-376, http://dx.doi.org/10.26471/cjees/2020/015/137.

8. Ionescu, P.; Radu, V-M.; Deak, G.; Diacu, E.; Ivanov, A. A.; Ciobotaru, I-E.; Marcu, E. Assessment of Potential Toxic Elements in Muscle Tissues of Different Fish Species from Colentina, Dambovita and Arges Rivers, Romania. Rev. Chim. 2020, 71, 19-28, https://doi.org/10.37358/RC.20.3.7969.

9. Radu, V-M.; Ionescu, P.; Diacu, E.; Deak, G.; Ivanov, A. A. Assessing and Spatio-Temporal Variations of Potentially Toxic Elements in the Sediments from Lower Danube River in 2011-2017 Period. Rev. Chim. 2020, 71, 126-135, https://doi.org/10.37358/RC.20.3.7980.

10. Demir, Y. The Effects of the Applications of Zeolite and Biochar to the Soils Irrigated with Treated Wastewater on the Heavy Metal Concentrations of the Soils and Leaching Waters from the Soils. Carpathian Journal of Earth and Environmental Sciences 2021, 16, 223-236, http://dx.doi.org/10.26471/cjees/2021/016/169.

11. Moraru, E.; Dontu O.; Baran, N.; Petre, A.; Moga, I. C. Experimental Researches on the Depollution of Wastewater by Forced Oxygenation and Ozonation. Rev. Chim. 2020, 71, 202-209, https://doi.org/10.37358/RC.20.9.8330.

12. Dragomir Balanica, C. M.; Muntenita, C.; Zeca, D. E.; Stoica, M. Statistical Analysis of the Physicochemical Characteristics of Urban Wastewater Treatment Plants from Romania. Rev. Chim. 2020, 71, 100-107, https://doi.org/10.37358/RC.20.10.8354.

13. Iova, A. R.; Neagu, C. V.; Cretu, D. Case Study Regarding the Variation of the Qualitative Parameters of Wastewater. Rev. Chim. 2021, 72, 1-8, https://doi.org/10.37358/RC.21.2.8414.

14. Mihalache, S. F.; Carbureanu, M. The Factorial Analysis of the Activated Sludge Treatment Process Parameters. Rev. Chim. 2020, 71, 75-85, https://doi.org/10.37358/RC.20.5.8115.

15. Klimša, L.; Melčáková, I.; Nováková, J.; Bártková, M.; Hlaváč, A.; Krakovská, A.; Dombek, V.; Andráš, P. Recipient Pollution Caused by Small Domestic Wastewater Treatment Plants with Activated Sludge. Carpathian Journal of Earth and Environmental Sciences 2020, 15, 19-25, https://doi.org/10.26471/cjees/2020/015/104.

16. Mincu, M.; Marcus, M.I.; Mitiu, M. A.; Raischi, N.S. Increasing the Efficiency of Pollutants Removal from Municipal Wastewater Using Biological Filters. Rev. Chim. 2018, 69, 3553-3556, https://doi.org/10.37358/RC.18.12.6790.

17. Bumbac, C.; Manea, E. E.; Banciu, A.; Stoica, C.; Ionescu, I.; Badescu, V.; Nita-Lazar, M. Identification of Physical, Morphological and Chemical Particularities of Mixed Microalgae-Bacteria Granules. Rev. Chim. 2019, 70, 275-277, https://doi.org/10.37358/RC.19.1.6898.

18. Gherman, V. D.; Molnar, P.; Motoc, M.; Negrea, A. Pretreatments Testing of High Biodiversity Inocula with Simultaneous Biohydrogen Production and Wastewater Treatment. Rev. Chim. 2018, 69, 806-808, https://doi.org/10.37358/RC.18.4.6205.

19. Manea, E.; Bumbac, C.; Banciu, A.; Stoica, C.; Nita-Lazar, M. Kinetical Parameters Evaluation for Microalgae-Bacteria Granules used for Waste Water Treatment. Rev. Chim. 2020, 71, 88-91, https://doi.org/10.37358/RC.20.1.7817. 
20. Biris-Dorhoi, E. S.; Tofana, M.; Chis, S. M.; Lupu, C. E.; Negreanu-Pirjol, T. Wastewater Treatment Using Marine Algae Biomass as Pollutants Removal. Rev. Chim. 2018, 69, 1089-1098, https://doi.org/10.37358/RC.18.5.6267.

21. Bartha, C.; Jipa, M.; Ignat, D. M.; Tókos, A.; Lingvay, I. The energy efficiency of domestic wastewater treatment processes: case analysis. EEA 2020, 68, 30-36, https://doi.org/10.46904/eea.20.68.4.1108004.

22. Amaroli, A.; Chessa, M. G.; Bavestrello, G.; Bianco, B. Effects of an extremely low-frequency electromagnetic field on stress factors: A study in Dictyostelium discoideum cells. Eur. J. Protistol 2013, 49, 400-405, https://doi.org/10.1016/j.ejop.2012.12.002.

23. Hashish, A. H.; El-Missiry, M. A.; Abdelkader, H. I.; Abou-Saleh, R. H. Assessment of biological changes of continuous whole body exposure to static magnetic field and extremely low frequency electromagnetic fields in mice. Ecotoxicol. Environ. Saf. 2008, 71, 895-902, https://doi.org/10.1016/j.ecoenv.2007.10.002.

24. Stancu, C.; Lingvay, M.; Szatmári, I.; Lingvay, I. Influence of $50 \mathrm{~Hz}$ Electromagnetic Field on the Yeast (Saccharomyces Cerevisiae) Metabolism. The 8th International Symposium on Advanced Topics in Electrical Engineering, Bucharest, Romania 2013, 1-4, https://doi.org/10.1109/ATEE.2013.6563449.

25. Gao, M.; Zhang, J.; Feng, H. Extremely Low Frequency Magnetic Field Effects on Metabolite of Aspergillus Niger. Bioelectromagnetics 2011, 32, 73-78, https://doi.org/10.1002/bem.20619.

26. Geada, P.; Rodrigues, R.; Loureiro, L. \& al. Electrotechnologies applied to microalgal biotechnology Applications, techniques and future trends. Renewable and Sustainable Energy Reviews 2018, 94, 656-668, https://doi.org/10.1016/j.rser.2018.06.059.

27. Hunt, R. W.; Zavalin, A.; Bhatnagar, A.; Chinnasamy, S.; Das, K. C. Electromagnetic Biostimulation of Living Cultures for Biotechnology, Biofuel and Bioenergy Applications. Int. J. Mol. Sci. 2009, 10, 45154558, https://dx.doi.org/10.3390/ijms10104515.

28. Filipič, J.; Kraigher, B.; Tepuš, B.; Kokol, V.; Mandic-Mulec, I. Effects of low-density static magnetic fields on the growth and activities of wastewater bacteria Escherichia coli and Pseudomonas putida. Bioresour. Technol. 2012, 120, 225-232, http://dx.doi.org/10.1016/j.biortech.2012.06.023.

29. Lingvay, M.; Caramitu, A-R.; Borș, A-M.; Lingvay, I. Dielectric spectroscopic evaluation in the extremely low frequency range of an Aspergillus Niger culture. Studia UBB Chemia 2019, 64, 279-288, http://dx.doi.org/10.24193/subbchem.2019.2.23.

30. Bartha, C.; Caramitu, A.; Jipa, M.; Ignat, D. M.; Tókos, A. Dielectric behavior of sludge from wastewater treatment, Studia UBB Chemia 2020, 65, 85-93, http://dx.doi.org/10.24193/subbchem.2020.4.07.

31. Raicu, V.; Feldman, Y. Dielectric Relaxation in Biological Systems: Physical Principles, Methods, and Applications. Oxford University Press, New York 2015, Chapter 2, https://doi.org/10.1093/ACPROF:OSO/9780199686513.001.0001.

32. Aronsson, K.; Ronner, U.; Borch, E. Inactivation of Escherichia coli, Listeria innocua and Saccharomyces cerevisiae in relation to membrane permeabilization and subsequent leakage of intracellular compounds due to pulsed electric field processing. Int. J. Food Microbiol. 2005, 99, 19-32, https://doi.org/10.1016/j.ijfoodmicro.2004.07.012.

33. Ferencz, C-M.; Petrovszki, P.; Dér, A., Sebők-Nagy, K.; Kóta, Z.; Páli, T. Oscillating Electric Field Measures the Rotation Rate in a Native Rotary Enzyme. Sci. Rep. 2017, 7, 45309, https://doi.org/10.1038/srep45309.

34. Fürst, P.; Stehle, P. What are the essential elements needed for the determination of amino acid requirements in humans? J. Nutr. 2004, 134, 1558-1565, https://doi.org/10.1093/jn/134.6.1558S.

35. Caramitu, A.; Butoi, N.; Rus, T.; Luchian, A-M.; Mitrea, S. The Resistance to the Action of Molds of Some Painting Materials Aged by Thermal Cycling and Exposed to an Electrical Field of $50 \mathrm{~Hz}$. Mat. Plast. 2017, 54, 331-337, https://doi.org/10.37358/MP.17.2.4845.

36. Prats, C.; López, D.; Giró, A.; Ferrer, J.; Valls, J. Individual-based modelling of bacterial cultures to study the microscopic causes of the lag phase, J. Theor. Biol. 2006, 241, 939-953, https://doi.org/10.1016/j.jtbi.2006.01.029.

37. Tókos, A.; Bartha, C.; Jipa, M.; Micu, D-D.; Caramitu A-R.; Lingvay, I. Interactions of Extremely LowFrequency Electric Field with the Active Sludge Live Materia from Wastewater Treatments. The $12^{\text {th }}$ International Symposium on Advanced Topics In Electrical Engineering 2021, Bucharest, Romania, IEEE Xplore, https://doi.org/10.1109/ATEE52255.2021.9425187.

38. Tókos, A.; Jipa, M.; Marinescu, V.; Bartha, C.; Caramitu, A-R.; Lingvay, I. Electromagnetic Stimulation of Microbial Activity in Wastewater Treatment: Experimental Equipment. EEA 2021, 69, 45-52, https://doi.org/10.46904/eea.21.69.2.1108005. 